\title{
ANALISIS EFISIENSI BIAYA DENGAN MENGGUNAKAN METODE LOT FOR LOT DALAM PENGENDALIAN PERSEDIAAN
}

\author{
Citra Anggraini ${ }^{1}$ \\ Pendidikan Akuntansi FKIP \\ Universitas PGRI Madiun \\ anggrainicitra105@yahoo.co.id
}

\author{
Isharijadi $^{2}$ \\ Pendidikan Akuntansi FKIP \\ Universitas PGRI Madiun
}

\section{Nik Amah ${ }^{3}$ \\ Pendidikan Akuntansi FKIP \\ Universitas PGRI Madiun}

\begin{abstract}
ABSTRAK
Tujuan penelitian ini untuk mengetahui terjadinya efisiensi biaya melalui metode lot for lot dalam mengendalikan persediaan pada PT. INKA (Persero) Madiun. Penelitian ini menggunakan pendekatan kualitatif dengan jenis penelitian deskriptif kualitatif. Teknik pengumpulan data menggunakan wawancara, observasi, dan dokumentasi dan untuk menguji keabsahan data dalam penelitian ini, digunakan triangulasi teknik. Hasil penelitian: menunjukkan bahwa perusahaan sudah menerapkan pengendalian persediaan dengan baik, dapat dilihat dari jumlah bahan baku produksi yang terpenuhi. Beberapa hal yang perlu diperhatikan guna meningkatkan pengendalian persediaan yaitu: jenis bahan baku dalam memproduksi Kereta Ekonomi (K3) AC terdiri dari 326.801,75 komponen bahan baku utama, harus dipisahkan sehingga memudahkan perhitungan kebutuhan proyek pada periode berikutnya. Perhitungan metode moving average yang diterapkan PT. INKA (Persero) Madiun saat ini masih mengeluarkan biaya penyimpanan yang besar sehingga terjadi pemborosan biaya pada perusahaan. Hasil perhitungan menunjukkan penggunaan metode lot for lot lebih efisien karena jumlah pesanan sesuai dengan kebutuhan yang akan diproduksi.
\end{abstract}

Kata Kunci : efisiensi biaya; metode lot for lot; pengendalian persediaan; PT. INKA (Persero) Madiun

\begin{abstract}
The purpose of this study to determine the occurrence of cost efficiency through the lot for lot method in controlling inventory at PT. INKA (Persero) Madiun. This research uses qualitative approach with descriptive qualitative research type. Technique of collecting data using interview, observation, and documentation and to test the validity of data in this research, used triangulation technique. Result of research: show that company have applying inventory control well, can be seen from amount of raw material of production fulfilled. Some things to note in order to improve inventory control are: the type of raw materials in producing Economic Train (K3) AC consists of 326,801.75 main raw material components, must be separated so as to facilitate the calculation of project needs in the next period. Calculation of moving average method applied by PT. INKA (Persero) Madiun is still spending a large cost of storage resulting in waste of costs on the company. The calculation results show the use of lot for lot method more efficient because the number of orders in accordance with the needs to be produced.
\end{abstract}

Keywords: $\quad$ Cost efficiency; Lot for lot method; Inventory control; PT. INKA (Persero) Madiun

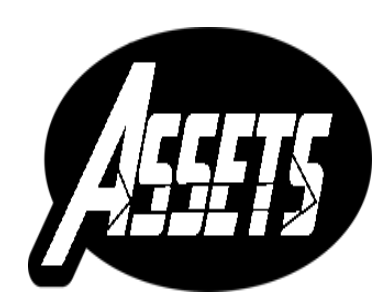

ASSETS

Jurnal Akuntansi dan Pendidikan

Vol. 6 No. 2

Hlmn. 142-152

Madiun, Oktober 2017 p-ISSN: 2302-6251 e-ISSN: 2477-4995

Artikel masuk: 2 Agustus 2017

Tanggal diterima: 25 Oktober 2017 


\section{PENDAHULUAN}

Perkembangan perusahaan industri manufaktur saat ini mengalami kemajuan sangat pesat yang menimbulkan persaingan yang sangat kuat antara perusahaan industri satu dengan yang lainya. Strategi agar dapat bertahan dalam persaingan tersebut, perusahaan industri manufaktur dapat mengembangkan sistem produksi yang efektif dan efisien untuk mendapatkan keuntungan yang sebesar-besarnya.

Usaha menghasilkan keuntungan merupakan hal yang paling utama dalam suatu perusahaan. Keuntungan dapat memberikan manfaat ekonomis yang tinggi bagi perusahaan sebagai alat untuk menunjang kegiatan operasionalnya agar dapat menjalankan kegiatanya secara terus menerus dan berkesinambungan (going concern). Selain itu, keuntungan juga dapat meningkatkan nilai perusahaan. Dalam usaha menghasilkan keuntungan selalu diikuti dengan pengorbanan sejumlah sumber daya yaitu biaya.

Biaya adalah suatu pengorbanan ekonomis oleh perusahaan yang akan menghasilkan keuntungan di masa mendatang. Meskipun biaya dapat menghasilkan keuntungan di masa yang akan datang, namun perusahaan tetap harus berusaha untuk melakukan efisiensi agar tidak terjadi pemborosan. Meskipun demikian, efisiensi bukan berarti pemangkasan biaya secara tidak terstruktur dan asal asalan. Gobel (2013: 1) menunjukkan bahwa efisiensi adalah suatu ukuran keberhasilan perusahaan yang dinilai dari besarnya sumber daya yang dikorbankan untuk memperoleh hasil yang telah ditetapkan. Peningkatan efisiensi biaya menyangkut perhitungan bahwa setiap rupiah yang dikeluarkan harus memperhitungkan tingkat kemanfaatan bagi pendapatan perusahaan.

Menurut Horngren, Datar, dan Foster (2008:7) menunjukkan bahwa biaya dan efisiensi (cost and efficiency) dilakukan oleh perusahaan dalam menghadapi tekanan yang terus-menerus untuk menurunkan biaya produk atau jasa yang mereka jual. Efisiensi adalah suatu ukuran keberhasilan yang dinilai dari besarnya sumber daya yang dikorbankan untuk memperoleh hasil tertentu. Perusahaan besar dengan jenis kegiatan yang beragam memiliki pengeluaran biaya yang tidak sedikit. Jika dibiarkan, pengeluaran tersebut dapat berdampak pada penurunan keuntungan yang dihasilkan perusahaan. Sedangkan Robbins dan Coulter (2010: 7-8) menyebutkan bahwa efisiensi merujuk pada maksud mendapatkan sebesar-besarnya output dari sekecil-kecilnya input. Karena manajer berhadapan dengan kelangkaan input termasuk sumbersumber daya semisal orang, uang, dan peralatan maka mereka berkepentingan untuk menggunakan sumber-sumber daya ini secara efisien. Hal ini sering kali dikatakan "mengerjakan sesuatu tepat sasaran" yaitu, tidak menyia-nyiakan sumber daya.

Perusahaan harus merencanakan sistem produksi agar dapat mencapai efisiensi dan memenuhi kebutuhan pelanggan pada waktu, jumlah dan produk yang sesuai dengan keinginan dan kebutuhannya. Untuk itu, perusahaan industri harus melakukan perbaikan terus menerus pada sistem produksi perusahaan khususnya dalam mengendalikan persediaannya demi menekan biaya yang dikeluarkan agar efisien. Pelaksanaan aktivitas produksi setiap perusahaan industri tidak lepas dari persediaan.

Dalam melaksanakan aktivitas produksinya, setiap perusahaan baik perusahaan jasa maupun perusahaan manufaktur pasti akan memerlukan adanya persediaan. Menurut Samryn (2015: 81) menyatakan bahwa persediaan meliputi aktiva berwujud yang dimiliki dengan tujuan untuk dijual kembali atau digunakan dalam proses produksi. Sedangkan Sofyan (2013: 49) memberikan pendapat bahwa persediaan dalam proses produksi dapat diartikan sebagai sumber daya menganggur, hal ini dikarenakan sumber daya tersebut masih menunggu dan belum digunakan pada 
proses berikutnya. Proses berikutnya yang dimaksud dapat berupa kegiatan produksi pada sistem manufaktur, kegiatan pemasaran pada sistem distribusi dan juga kegiatan konsumsi pada sistem kebutuhan rumah tangga.

Sedangkan menurut Handoko (2014: 333) mengemukakan bahwa "istilah persediaan (inventory) adalah suatu istilah umum yang menunjukkan segala sesuatu atau sumber daya-sumber daya organisasi yang disimpan dalam antisipasinya terhadap pemenuhan permintaan". Ristono (2013: 1) menyatakan "persediaan dapat diartikan sebagai barang-barang yang disimpan untuk digunakan atau dijual pada masa atau periode yang akan datang. Persediaan terdiri dari persediaan bahan baku, persediaan bahan setengah jadi dan persediaan bahan jadi". Berdasar pendapat ahli diatas dapat disimpulkan bahwa persediaan sangat penting bagi kegiatan operasional perusahaan. Ketiadaan persediaan dalam perusahaan akan menimbulkan dampak yang buruk karena tidak bisa memenuhi permintaan konsumen, kebutuhan bahan untuk produksi tidak bisa tercukupi, kelancaran produksi terganggu dan kekurangan bahan baku untuk di proses. Sebaliknya, jika persediaan digudang kelebihan akan menimbulkan kenaikan biaya penyimpanan, biaya kerusakan bahan selama penyimpanan dan keusangan bahan, menambah kebutuhan modal untuk investasi dan memerlukan tempat yang luas dari sebelumnya. Oleh karena itu, jumlah persediaan barang sebaiknya tidak terlalu banyak dan tidak terlalu sedikit.

Sebagaimana pernyataan Sofyan (2013: 105) bahwa penentuan jumlah persediaan barang yang sesuai kebutuhan perlu menggunakan metode lot for lot (jumlah pesanan sesuai permintaan). Metode ini merupakan pendekatan persediaan yang dilakukan atas dasar pesanan diskrit dengan pertimbangan minimasi dari ongkos simpan, jumlah yang dipesan sama dengan jumlah yang dibutuhkan. Penggunaan teknik ini bertujuan untuk memininumkan ongkos simpan, sehingga dengan teknik ini ongkos simpan menjadi nol.

PT. INKA (Persero) Madiun merupakan perusahaan industri manufaktur, sebagai salah satu badan usaha milik negara terus mengalami perkembangan, diawali pada tahun 1981 dengan produk berupa kereta penumpang kelas ekonomi dan gerbong barang kini menjadi industri manufaktur perkeretaapian yang modern. Aktivitas bisnis PT. INKA (Persero) Madiun yang ada kini berkembang mulai dari penghasil produk dasar menjadi penghasil produk dan jasa perkeretaapian dan transportasi yang bernilai tinggi. Perbaikan dan pembaharuan yang dilakukan secara berkesinambungan merupakan upaya PT. INKA (Persero) Madiun beradaptasi terhadap persaingan global. PT. INKA (Persero) Madiun memasuki dunia bisnis ini dengan mengedepankan nilai-nilai integritas, profesional dan kualitas. Untuk menghadapi tantangan dunia bisnis ke depan, PT. INKA (Persero) Madiun tidak hanya bergelut dalam produk-produk perkeretaapian, namun menghasilkan produk lain yang lebih luas yang mampu memberikan kontribusi terhadap permintaan infrastruktur dan sarana transportasi.

PT. INKA (Persero) Madiun sebagai perusahaan manufaktur tentunya memiliki persediaan untuk memproduksi barang yang akan dipasarkan kepada konsumen atau memproduksi barang yang dipesan oleh konsumen. Setiap pembelian persediaan PT INKA (Persero) Madiun mengeluarkan biaya-biaya yang telah ditetapkan. Selama ini PT. INKA (Persero) Madiun menggunakan metode moving average untuk menentukan biaya-biaya yang dikeluarkan terkait persediaan barang. Samryn (2015: 95) mengemukakan bahwa dalam metode rata-rata bergerak nilai rata-rata persediaan dihitung secara bergerak dari hari ke hari. Pada metode ini, biaya rata-rata per unit yang baru akan dihitung setiap kali pembelian dilakukan". Sedangkan menurut 
Mardiasmo (2012: 107) mengemukakan metode rata-rata ini digunakan pada perusahaan yang menggunakan metode perpetual dalam mencatat persediaan.

Berdasarkan definisi di atas peneliti menyimpulkan bahwa metode moving average (rata-rata bergerak) adalah metode peramalan perataan nilai dengan mengambil sekelompok nilai pengamatan yang kemudian dicari rata-ratanya, lalu menggunakan rata-rata tersebut sebagai ramalan untuk periode berikutnya. Penerapan metode ini dapat mengakibatkan barang persediaan yang tersisa atau terjadinya kekurangan barang persediaan karena dalam menentukan persediaan hanya menggunakan rata-rata. Sedangkan pada PT. INKA (Persero) Madiun setiap melaksanakan kegiatan operasional menghasilkan jumlah produk yang tidak tetap setiap proyek. Hal ini berarti setiap menjalankan kegiatan operasional dalam satu proyek PT. INKA (Persero) Madiun membutuhkan jumlah persediaan yang berbedabeda. Sehingga dalam penerapan metode moving average tersebut belum berjalan dengan baik karena pada saat proyek selesai barang persediaan masih banyak yang menumpuk di gudang mengakibatkan biaya tidak efisien.

Salah satu aktivitas yang penting bagi perusahaan adalah persediaan. Persediaan merupakan stock yang dibutuhkan perusahaan untuk mengatasi adanya fluktuasi permintaan. Persediaan juga merupakan salah satu unsur paling aktif dalam operasi perusahaan yang secara terus-menerus diperoleh, diubah, yang kemudian dijual kembali. Sebagian besar sumber perusahaan juga sering dikaitkan di dalam persediaan yang akan digunakan dalam perusahaan pabrik. Persediaan memungkinkan terlaksananya operasi produksi, karena faktor waktu antara operasi itu dapat diminimalkan atau dihilangkan sama sekali. Oleh sebab itu, perusahaan perlu mengadakan pengendalian terhadap persediaan.

Pengendalian persediaan merupakan fungsi manajerial yang sangat penting, karena persediaan phisik banyak perusahaan melibatkan investasi rupiah terbesar dalam pos aktiva lancar. Bila perusahaan menanamkan terlalu banyak dananya dalam persediaan, menyebabkan biaya penyimpanan yang berlebihan, dan mungkin mempunyai "opportunity cost" (Handoko, 2014: 333). Demikian pula, bila perusahaan tidak mempunyai persediaan yang mencukupi, dapat mengakibatkan biaya-biaya dari terjadinya kekurangan bahan.

Pengendalian berkaitan dengan efisien biaya agar tercipta suatu kondisi yang baik dalam kegiatan operasional perusahaan. Jika perusahaan sudah melakukan pengendalian persediaan dengan baik maka ketersediaan bahan baku dalam perusahaan akan sesuai dengan kebutuhan. Kegiatan operasional PT. INKA (Persero) Madiun terkait produksi tidak tetap setiap tahunnya. Metode lot for lot bertujuan untuk meminimumkan jumlah persediaan barang di gudang. Metode ini dapat meminimalisir pengeluaran biaya sehingga biaya yang dikeluarkan perusahaan akan lebih efisien. Selain itu, metode lot for lot dilihat dari pola kebutuhan yang mempunyai sifat diskontinu atau tidak teratur maka teknik lot for lot ini memiliki kemampuan yang baik, disamping itu teknik ini sering digunakan pada sistem produksi manufaktur yang mempunyai sifat setup permanen pada proses produksinya.

Lot for lot, sering disingkat L4L. Dalam L4L, pemesanan hanya dilakukan untuk memenuhi kebutuhan selama satu minggu saja, karena tujuannya memang untuk meminimunkan jumlah persediaan barang di gudang. Untuk mencari jumlah pesanan dilakukan dengan cara sebagai berikut:

Jumlah pemesanan $=[$ kebutuhan minggu ke $t+$ safety stock - persediaan awal $]$

(Subagyo, 2009: 152-153). 
Berdasarkan latar belakang masalah yang telah dipaparkan di atas, maka penelitian ini berusaha untuk menjawab pertanyaan "bagaimana mengefisiensi biaya dengan menggunakan metode lot for lot dalam pengendalian persediaan. Tujuan yang ingin dicapai dari penelitian ini adalah untuk mengetahui terjadinya efisiensi biaya melalui metode lot for lot dalam mengendalikan persediaan pada PT. INKA (Persero) Madiun).

\section{METODE PENELITIAN}

Jenis penelitian ini merupakan penelitian deskriptif kualitatif, yaitu penelitian yang terbatas pada usaha-usaha yang mengungkapkan suatu masalah atau keadaan atau peristiwa sebagaimana adanya sehingga bersifat sekedar mengungkapkan fakta (fact finding). Sugiyono (2013: 9) menyebutkan "metode penelitian kualitatif dapat diartikan sebagai metode penelitian yang berlandaskan pada filsafat postpositivisme, digunakan untuk meneliti pada kondisi obyek yang alamiah, (sebagai lawannya adalah eksperimen) dimana peneliti adalah sebagai instrument kunci, teknik pengumpulan data dilakukan secara triangulasi (gabungan), analisis data bersifat induktif/kualitatif, dan hasil penelitian kualitatif lebih menekankan makna dari pada generalisasi". Penelitian deskriptif dalam penelitian ini bertujuan mengungkapkan data-data empiris yang ada di lapangan dengan cara menguraikan dan menginterpretasikan suatu fenomena dengan apa adanya terhadap sesuatu yang terjadi pada saat penelitian, agar diperoleh gambaran realita yang konkret mengenai hal yang diteliti.

Data yang digunakan dalam penelitian ini meliputi data primer dan data sekunder. Data primer dalam penelitian ini diperoleh dari wawancara dengan divisi logistik manajer departemen perencanaan, pengendalian, pengadaan dan persediaan logistik serta divisi keuangan manajer akuntansi perusahaan mengenai data laporan keuangan yang menyangkut biaya persediaan perusahaan PT. INKA (Persero) di Kota Madiun. Data sekunder diperoleh dari studi pustaka berupa literatur, jurnal, maupun referensi dari sumber lain yang terkait dengan teori-teori tentang efisiensi biaya, metode lot for lot, serta pengendalian persediaan. Instrumen yang digunakan dalam penelitian adalah wawancara. Wawancara digunakan untuk mengumpulkan data-data tentang efisiensi biaya yang sudah dijalankan dan pengendalian persediaan pada PT. INKA (Persero) Madiun. Dalam penelitian ini teknik pengumpulan data dengan dokumen merupakan pelengkap dari penggunaan wawancara dan observasi dimana dalam dokumen yang berfokus pada penyajian laporan keuangan mengenai biaya dalam persediaan perusahaan. Teknik keabsahan data yang digunakan dalam penelitian ini adalah triangulasi sumber dan triangulasi teknik pengumpulan data. Penelitian ini menggunakan teknik analisis data yang bersifat kualitatif, dengan data yang diperoleh dari hasil wawancara, observasi, dan dokumen serta dikumpulkan dan dikelompokkan berdasarkan fakta di lapangan serta menafsirkan dan membuat makna dari data yang sudah dikumpulkan.

\section{HASIL PENELITIAN DAN PEMBAHASAN}

Analisis biaya yang dikeluarkan PT. INKA (Persero) Madiun pada tahun 2016 menggunakan metode moving average. Metode moving average mengitung biaya ratarata per unit ketika pembelian dilakukan. Hal ini berarti dalam menentukan jumlah persediaan yang akan dipesan PT. INKA (Persero) Madiun menggunakan jumlah ratarata dari jumlah persediaan periode sebelumnya atau dalam proyek sebelumnya. Untuk pengambilan keputusan penentuan besarnya jumlah persediaan maka PT. INKA (Persero) Madiun harus mempertimbangkan biaya pemesanan dan biaya 
penyimpanan. Berdasarkan perhitungan biaya pemesanan PT. INKA (Persero) Madiun pada tahun 2016 diperoleh biaya sebesar Rp 67.925.000,00. Tahun 2016 PT. INKA (Persero) Madiun melakukan 1 kali pemesanan pada 1 proyek yang diselesaikan. Jumlah persediaan yang dipesan adalah sebanyak $326.801,75$ untuk 1 periode.

Setelah proyek selesai dikerjakan ternyata masih ada persediaan yang tersisa di gudang. Hal ini disebabkan oleh penentuan persediaan PT. INKA (Persero) Madiun hanya menggunakan rata-rata bukan sesuai dengan jumlah persediaan yang dibutuhkan. Timbulnya persediaan yang tersisa mengindikasikan bahwa perusahaan kurang efisien dalam melakukan pengendalian persediaan. Perusahaan juga mengalami peningkatan biaya yang harus dikeluarkan untuk memelihara persediaan di gudang. Untuk memelihara persediaan di gudang PT. INKA (Persero) Madiun harus mengeluarkan biaya simpan. Terdapat banyak persediaan yang tersisa digudang sejumlah 14 bahan baku maka biaya simpan yang dikeluarkan perusahaan adalah sebesar Rp 252.827.246,00. Biaya ini digunakan untuk menjaga dan memelihara persediaan di dalam gudang. Oleh karena itu, biaya yang harus dikeluarkan PT. INKA (Persero) Madiun dalam menentukan jumlah persediaan adalah sebesar Rp 320.752.246,00. Persediaan yang dibeli oleh perusahaan tidak mengalami kekurangan, tetapi menyebabkan kelebihan persediaan pada saaat proses produksi selesai dikerjakan shingga menimbulkan biaya simpan yang harus dikeluarkan perusahaan. Timbulnya sisa persediaan setelah perusahaan menyelesaikan proyek disebabkan jumlah persediaan yang dibeli tidak sesuai dengan kebutuhan. Hal ini mengindikasikan bahwa pengendalian persediaan yang diterapkan oleh PT. INKA (Persero) Madiun kurang efisien karena pengendalian persediaan dikatakan efisien apabila pengukuran atau penentuan terhadap bahan baku sampai bahan jadi tidak menyebabkan kekurangan atau kelebihan pada saat proses produks sehingga idak mengakibatkan perusahaan mengalami pemborosan biaya.

Analisis biaya yang dikeluarkan PT. INKA (Persero) Madiun pada tahun 2016 menggunakan metode lot for lot dilaksanakan untuk membuat perbandingan metode manakah yang paling baik dipakai oleh perusahaan dalam menentukan jumlah pesanan persediaan. Pada metode lot for lot akan diketahui jumlah pemesanan persediaan atau jumlah persediaan yang dibeli sama dengan jumlah kebutuhan perusahaan. Penggunaan metode lot for lot akan memberikan dampak baik bagi perusahaan karena bertujuan untuk memininumkan ongkos simpan, sehingga dengan metode ini ongkos simpan menjadi nol. Oleh karena itu, dalam menentukan jumlah persediaan barang yang sesuai kebutuhan perlu menggunakan metode lot for lot (jumlah pesanan sesuai permintaan) karena pendekatan menggunakan teknik ini dilakukan atas dasar pesanan diskrit dengan pertimbangan minimasi dari ongkos simpan, jumlah yang dipesan sama dengan jumlah yang dibutuhkan.

PT. INKA (Persero) Madiun menerapkan sistem kerja full time dimana selama 24 jam karyawan bekerja penuh sehingga tidak diperlukan ongkos simpan atau ongkos simpan dapat dinolkan. Hal tersebut dapat mengefisiensikan biaya yang di keluarkan oleh PT. INKA (Persero) Madiun sehingga penggunaan metode lot for lot lebih baik digunakan oleh PT. INKA (Persero) Madiun. Selain itu, metode lot for lot dilihat dari pola kebutuhan yang mempunyai sifat diskontinu atau tidak teratur maka teknik lot for lot ini memiliki kemampuan yang baik. Di samping itu teknik ini sering digunakan pada sistem produksi manufaktur yang mempunyai sifat setup permanen pada proses produksinya. Hal ini sesuai dengan sistem produksi yang diterapkan PT. INKA (Persero) Madiun, karena perusahaan menghasilkan produk dengan jumlah yang berbeda-beda setiap proyeknya. 
Berikut ini ditunjukkan hasil perhitungan biaya yang dikeluarkan PT. INKA (Persero) Madiun pada tahun 2016 dengan menggunakan metode moving average dibandingkan dengan perhitungan menggunakan metode lot for lot. Perbandingan jumlah biaya yang dikeluarkan PT. INKA (Persero) Madiun dapat dilihat pada Tabel 1.

Tabel 1 Perbandingan Total Biaya Persediaan menggunakan metode moving average dengan menggunakan metode lot fot lot

\begin{tabular}{|c|c|c|c|}
\hline \multirow{3}{*}{ Keterangan } & \multicolumn{2}{|c|}{ Metode yang Digunakan } & \multirow[b]{2}{*}{ Penghematan } \\
\hline & $\begin{array}{l}\text { Moving } \\
\text { Average }\end{array}$ & Lot for Lot & \\
\hline & \multicolumn{3}{|c|}{$\mathrm{Rp}$} \\
\hline Total Biaya Pemesanan & 67.925 .000 & 67.925 .000 & 0 \\
\hline Total Biaya Penyimpanan & 252.827 .246 & 0 & 252.827 .246 \\
\hline Total Biaya Persediaan & 320.752 .246 & 67.925 .000 & 252.827 .246 \\
\hline
\end{tabular}

Berdasarkan hasil perhitungan yang telah dilakukan, maka terdapat perbedaan pada total biaya persediaan antara perhitungan menggunakan metode moving average dengan perhitungan menggunakan metode lot for lot. Dimana adanya penghematan sebesar Rp 252.827.246,00 jika PT. INKA (Persero) Madiun menerapkan metode lot for lot dibandingkan dengan menerapkan metode moving average seperti saat ini yang ada di perusahaan. PT. INKA (Persero) Madiun melakukan pemesanan satu kali setiap kali adanya proyek atau kegiatan produksi yang diselesaikan selama 7 bulan pengerjaan.

Dilihat dari total biaya penyimpanan persediaan, total biaya penyimpanan dengan menggunakan metode lot for lot juga lebih kecil dibandingkan dengan menggunakan metode moving average atau total biaya penyimpanan pada metode lot for lot dapat dinolkan. Hal ini disebabkan karena jumlah bahan baku yang dipesan sama dengan jumlah bahan baku yang dibutuhkan dalam proses produksi PT. INKA (Persero) Madiun, dan persediaan bahan baku yang dibeli atau dipesan akan langsung digunakan pada proses produksi dengan sistem kerja full time sehingga tidak diperlukan biaya penyimpanan untuk persediaan yang tersisa. Sedangkan pada penerapan metode moving average, pemesanan atau penentuan jumlah bahan baku seringkali tidak melihat jumlah kebutuhan yang sebenarnya untuk kegiatan produksi, sehingga setelah proyek selesai masih terdapat persediaan yang tersisa atau terjadi penumpukan persediaan di dalam gudang. Hal ini mengakibatkan timbulnya biaya penyimpanan yang besar pada metode moving average.

Metode lot for lot memberikan perencanaan kebutuhan bahan baku yang lebih efisien dibandingkan dengan perencanaan kebutuhan bahan baku yang hanya berdasarkan nilai rata-rata saja, perusahaan lebih baik menerapkan metode lot for lot agar dapat meminimumkan total biaya persediaan sehingga biaya yang dikeluarkan oleh perusahaan lebih efisien.

Pada setiap minggunya diperkirakan PT INKA (Persero) Madiun ini dapat memproduksi sekitar 2 kereta ekonomi (K3) AC setiap kereta yang diproduksi terdapat sejumlah kebutuhan bahan baku sekitar 5.941,85 untuk pembuatan 1 kereta jadi jika dalam setiap minggunya memproduksi 2 kereta maka jumlah kebutuhan bahan baku sekitar11.883,70. Untuk proyek yang akan dikerjakan oleh PT INKA (Persero) Madiun sebanyak 5 trainset kereta ekonomi (K3) AC pada setiap 1 trainset terdapat 11 kereta jadi 5 trainset kereta ekonomi (K3) AC sejumlah 55 kereta. Proyek tersebut akan diselesaikan kurang lebih selama 7 bulan. 
Untuk merencanakan kebutuhan pada proyek agar tidak terjadi kelebihan atau kekurangan pada persediaaan dengan menggunakan metodelot for lot maka kebutuhan pada setiap minggunya sebagai berikut:

Tabel 2 Rencana Kebutuhan Bahan Baku dengan Metode Lot For Lot

\begin{tabular}{|c|c|c|c|c|}
\hline \multicolumn{5}{|c|}{ Bulan ke 1} \\
\hline Minggu & 1 & 2 & 3 & 4 \\
\hline Kebutuhan Bersih & $11.883,70$ & $11.883,70$ & $11.883,70$ & $11.883,70$ \\
\hline Rencana Pemesanan & $326.801,75$ & & & \\
\hline \multicolumn{5}{|c|}{ Bulan ke 2} \\
\hline Kebutuhan Bersih & $11.883,70$ & $11.883,70$ & $11.883,70$ & $11.883,70$ \\
\hline \multicolumn{5}{|c|}{ Bulan ke 3} \\
\hline Kebutuhan Bersih & $11.883,70$ & $11.883,70$ & $11.883,70$ & $11.883,70$ \\
\hline \multicolumn{5}{|c|}{ Bulan ke 4} \\
\hline Kebutuhan Bersih & $11.883,70$ & $11.883,70$ & $11.883,70$ & $11.883,70$ \\
\hline \multicolumn{5}{|c|}{ Bulan ke 5} \\
\hline Kebutuhan Bersih & $11.883,70$ & $11.883,70$ & $11.883,70$ & $11.883,70$ \\
\hline \multicolumn{5}{|c|}{ Bulan ke 6} \\
\hline Kebutuhan Bersih & $11.883,70$ & $11.883,70$ & $11.883,70$ & $11.883,70$ \\
\hline \multicolumn{5}{|c|}{ Bulan ke 7} \\
\hline Kebutuhan Bersih & $11.883,70$ & $11.883,70$ & $11.883,70$ & $5.941,85$ \\
\hline
\end{tabular}

\section{SIMPULAN}

Berdasarkan hasil analisis data dan pembahasan yang disampaikan sebelumnya, maka dalam penelitian ini dapat disimpulkan bahwa hasil analisis efisiensi biaya dengan menggunakan metode lot for lot dalam pengendalian persediaan pada PT. INKA (Persero) Madiun menunjukkan bahwa secara umum PT. INKA (Persero) Madiun telah menerapkan pengendalian persediaan dengan baik, dapat dilihat dari jumlah bahan baku produksi yang terpenuhi atau tidak terjadi kekurangan bahan baku pada kegiatan produksinya sehingga tidak banyak bahan baku yang tersisa digudang setelah proyek selesai dikerjakan. Keterbatasan dalam penelitian ini data yang digunakan hanya laporan keuangan perusahaan tahun 2016 mengenai biaya persediaan yang dikeluarkan perusahaan khususnya biaya pemesanan dan biaya penyimpanan. Kurangnya perincian biaya penyimpanan mengakibatkan pengolahan data terbatas hanya pada data yang di dapat. Selain itu, kurangnya perolehan data dari divisi produksi yang terkait dengan produksi Kereta Ekonomi (K3) AC sehingga data kurang lengkap untuk hasil yang lebih baik.

Beberapa saran bagi perusahaan, khususnya pihak manajemen PT. INKA (Persero) Madiun sebagai berikut:

1. Untuk dapat mengendalikan persediaan digudang agar tidak menumpuk pada saat proyek sudah selesai sebaiknya perusahaan memperhatikan kebutuhan yang akan dibeli pada proyek selanjutnya dan lebih memperhatikan pemotongan plat dalam pembuatan car body agar tidak banyak yang tersisa.

2. Dengan menggunakan metode lot for lot yang sesuai dengan kebutuhan dapat meminimalisir banyaknya persediaan yang tersisa digudang sehingga persediaan dapat dikendalikan dan tidak menimbulkan pemborosan biaya atau lebih efisien.

3. Untuk penelitian selanjutnya yang dapat disarankan metode pengendalian persediaan yang digunakan adalah metode bersifat Stokastik. 


\section{DAFTAR PUSTAKA}

Gobel, M. (2013). Analisis Efisiensi Biaya Operasional melalui Pengelolaan Tunjangan Makan dan Jaminan Pemeliharaan Kesehatan pada Perusahaan Jasa Outsourcing.Jurnal EMBA. Vol. 1(4) : 1868-1878.

Handoko, T. H. (2014). Dasar-Dasar Manajemen Produksi dan Operasi. Yogyakarta: BPFEYogyakarta

Horngren, C. T., Datar, S. M., dan Foster, G. (2008). Akuntansi Biaya, Penekanan Manajerial. Jilid 1. Terjemahan Lestari. Jakarta: Erlangga.

Limbong, I., Tarore, H., Tjakra, J., dan Walangitan, D. R. O. (2013). Manajemen Pengadaan Material Bangunan dengan Menggunakan Metode MRP (Material Requirement Planning) Studi Kasus: Revitalisasi Gedung Kantor BPS Propinsi Sulawesi Utara. Jurnal Sipil Statik. Vol. 1 (6) : 1-9.

Mardiasmo. (2012). Akuntansi Keuangan Dasar 2 Edisi Kedua. Yogyakarta: BPFEYogyakarta.

Martani, D., Siregar, S. V., Wardhani, R. F., Aria, T., dan Edward. (2016). Akuntansi Keuangan Menengah Berbasis PSAK Edisi 2 Buku 1. Jakarta: Salemba Empat.

Ristono, A. (2013). Manajemen Persediaan. Yogyakarta: Graha Ilmu

Robbins, S. P. dan Coulter, M. (2010). Manajemen. Edisi Kesepuluh Jilid 1. Penerjemah: Bob Sabran dan Devri Barnadi Putera. Jakarta: Erlangga

Samryn, L. M. (2015). Pengantar Akuntansi: Buku 2 Metode Akuntansi untuk Elemen Laporan Keuangan Diperkaya dengan Perspektif IFRS dan Perbankan. Jakarta: PT. RajaGrafindo Persada.

Sofyan, D. K. (2013). Perencanaan dan Pengendalian Produksi. EdisiPertama. Yogyakarta: Graha Ilmu.

Subagyo, P. (2009). Manajemen Operasi. Edisi Pertama. Yogyakarta: BPFE-Yogyakarta.

Sugiyono. (2013). Metode Penelitian Pendekatan Kuantitatif. Kualitatif. R \& D. Bandung: Alfabeta.

Teurah, M. C. (2014). Analisis Pengendalian Persediaan Bahan Baku Ikan Tuna pada CV. Golden KK. Jurnal EMBA. Vol. 2. No. 4. Hal. 524-536.

Wahyuni, A. dan Syaichu, A. (2015). Perencanaan Persediaan Bahan Baku dengan Menggunakan Metode Material Requirement Planning (MRP) Produk Kacang Shanghai pada Perusahaan Gangsar Ngunut-Tulungagung. Jurnal Spektrum Industri. Vol. 13(2) : 115-228. 


\section{LAMPIRAN}

Pedoman Wawancara (Transkip Wawancara)

\begin{tabular}{|c|l|}
\hline \multicolumn{1}{|c|}{$\mathbf{N o}$} & \multicolumn{1}{|c|}{ Pertanyaan } \\
\hline 1 & $\begin{array}{l}\text { Bagaimanakah kebijakan perusahaan dalam menentukan biaya persediaan } \\
\text { pada PT. INKA (Persero) Madiun? }\end{array}$ \\
\hline 2 & $\begin{array}{l}\text { Bagaimanakah manajemen PT. INKA (Persero) Madiun dalam menerapkan } \\
\text { pengendalian persediaan? }\end{array}$ \\
\hline 3 & $\begin{array}{l}\text { Apakah selama ini terdapat masalah mengenai persediaan digudang terkait } \\
\text { produksi Kereta Ekonomi (K3) AC setelah proyek selesai dikerjakan? }\end{array}$ \\
\hline 4 & $\begin{array}{l}\text { Bagaimanakah keberlanjutan penggunaan persediaan yang masih banyak } \\
\text { tersisa digudang tersebut? }\end{array}$ \\
\hline 5 & $\begin{array}{l}\text { Apakah pengendalian persediaan yang diterapkan manajemen PT. INKA } \\
\text { (Persero) Madiun ini mendukung keberhasilan pengelolaan manajemen? }\end{array}$ \\
\hline 6 & $\begin{array}{l}\text { Apakah setiap pembelian kebutuhan bahan baku untuk memproduksi } \\
\text { Kereta Ekonomi (K3) AC pada PT. INKA (Persero) Madiun dilakukan } \\
\text { pencatatan? }\end{array}$ \\
\hline 7 & $\begin{array}{l}\text { Apakah biaya yang dikeluarkan PT. INKA (Persero) Madiun untuk } \\
\text { membeli persediaan selama ini sudah efisien? }\end{array}$ \\
\hline
\end{tabular}

DATA CAR BODY YANG TERSISA

\begin{tabular}{|c|l|c|c|}
\hline No. & Bahan Baku Utama & Satuan Bahan Baku & $\begin{array}{c}\text { Sisa Bahan Baku } \\
\text { Setelah Pemakaian }\end{array}$ \\
\hline 1. & PLATE SUS & LEMBAR & 2,46 \\
\hline 2. & PLATE SUS 400 & LEMBAR & 5,38 \\
\hline 3. & STEEL PLAT SPHC & LEMBAR & 10,31 \\
\hline 4. & KARET JEPIT PINTU & METER & 12,75 \\
\hline 5. & PIPA SCH SEAMLEES & BATANG & 19,15 \\
\hline 6. & TRIPLEK & LEMBAR & 13 \\
\hline 7. & SELANG ANGIN BENING & METER & 15,25 \\
\hline 8. & SENG BJIS & LEMBAR & 25,13 \\
\hline 9. & KAWAT TAMPAR BAJA & METER & 45,13 \\
\hline 10. & KABEL WL 1 KYUNGSHIN & METER & 95,13 \\
\hline 11. & PIPA SGP PUTIH GALV & BATANG & 12,13 \\
\hline 12. & PROTECTION EDGE & ROL & 38,24 \\
\hline 13. & BETON YZER & BATANG & 34,25 \\
\hline 14. & STEEL PLATE SS 450 & LEMBAR & 52,08 \\
\hline
\end{tabular}

Sumber: Divisi Logistik Departemen Perencanaan dan Pengendalian Pengadaan Persediaan, 2016

\section{TOTAL BIAYA PERSEDIAAN}

Berikut total persediaan yang diperoleh dari divisi keuangan departemen akuntansi dan divisi logistik departemen perencanaan dan pengendalian pengadaan persediaan yang dikeluarkan oleh PT. INKA (Persero) Madiun Kereta Ekonomi (K3) AC Tahun 2016: 
ANGGRAINI, C., ISHARIJADI DAN AMAH, N.

\begin{tabular}{|c|c|c|c|}
\hline \multicolumn{4}{|c|}{ Informan/Narasumber } \\
\hline \multicolumn{2}{|c|}{ Divisi Keuangan Departemen Akuntansi } & \multicolumn{2}{|c|}{$\begin{array}{l}\text { Divisi Logistik Departemen Perencanaan } \\
\text { dan Pengendalian Pengadaan Persediaan }\end{array}$} \\
\hline Biaya Pemesanan & Jumlah & Biaya Pemesanan & Jumlah \\
\hline $\begin{array}{l}\text { Biaya Persiapan } \\
\text { Pemesanan }\end{array}$ & Rp $11.000 .000,00$ & $\begin{array}{l}\text { Biaya Persiapan } \\
\text { Pemesanan }\end{array}$ & Rp $11.000 .000,00$ \\
\hline Biaya Administrasi & $5.700 .000,00$ & Biaya Administrasi & $5.700 .000,00$ \\
\hline $\begin{array}{l}\text { Biaya Angkut } \\
\text { Material }\end{array}$ & $9.350 .000,00$ & $\begin{array}{l}\text { Biaya Angkut } \\
\text { Material }\end{array}$ & $9.350 .000,00$ \\
\hline Biaya Pembukaan LC & $3.000 .000,00$ & Biaya Pembukaan LC & $3.000 .000,00$ \\
\hline $\begin{array}{l}\text { Biaya } \\
\text { Pengiriman/Perjalan } \\
\text { an Dinas }\end{array}$ & Rp $29.975 .000,00$ & $\begin{array}{l}\text { Biaya } \\
\text { Pengiriman/Perjalan } \\
\text { an Dinas }\end{array}$ & $\operatorname{Rp} \quad 29.975 .000,00$ \\
\hline $\begin{array}{l}\text { Biaya Penerimaan } \\
\text { Pemesanan }\end{array}$ & $4.700 .000,00$ & $\begin{array}{l}\text { Biaya Penerimaan } \\
\text { Pemesanan }\end{array}$ & $4.700 .000,00$ \\
\hline $\begin{array}{l}\text { Biaya Penyelesaian } \\
\text { Pemesanan }\end{array}$ & Rp $\quad 4.200 .000,00$ & $\begin{array}{l}\text { Biaya Penyelesaian } \\
\text { Pemesanan }\end{array}$ & $4.200 .000,00$ \\
\hline Total & Rp $67.925 .000,00$ & Total & Rp $67.925 .000,00$ \\
\hline Biaya penyimpanan & Jumlah & Biaya penyimpanan & Jumlah \\
\hline $\begin{array}{l}\text { Biaya Pemeliharaan } \\
\text { Bahan }\end{array}$ & $\begin{array}{ll}\mathrm{Rp} & 5.000 .000,00\end{array}$ & $\begin{array}{l}\text { Biaya Pemeliharaan } \\
\text { Bahan }\end{array}$ & $5.000 .000,00$ \\
\hline Biaya Asuransi Bahan & $2.000 .000,00$ & $\begin{array}{l}\text { Biaya Asuransi } \\
\text { Bahan }\end{array}$ & $2.000 .000,00$ \\
\hline $\begin{array}{l}\text { Biaya Tenaga Kerja di } \\
\text { Gudang }\end{array}$ & $7.159 .089,00$ & $\begin{array}{l}\text { Biaya Tenaga Kerja } \\
\text { di Gudang }\end{array}$ & $7.159 .089,00$ \\
\hline $\begin{array}{l}\text { Biaya Kerusakan } \\
\text { Bahan Baku }\end{array}$ & $3.900 .000,00$ & $\begin{array}{l}\text { Biaya Kerusakan } \\
\text { Bahan Baku }\end{array}$ & $3.900 .000,00$ \\
\hline Total & $\operatorname{Rp} 18.059 .089,00$ & Total & Rp 18. 059.089,00 \\
\hline
\end{tabular}

Jumlah persediaan yang masih tersisa adalah sebanyak 14 unit bahan baku untuk pembuatan Kereta Ekonomi (K3) AC.

$\begin{array}{lll}\text { Biaya Penyimpanan } & = & \sum \text { inventory } \times \text { biaya simpan/unit/bulan } \\ & = & 14 \times \operatorname{Rp~} 18.059 .089,00 \\ \text { Total Biaya Persediaan } & = & \text { B } 252.827 .246,00 / \text { proyek } \\ & = & R p 67.925 .000,00+\text { Rp } 252.827 .246,00 \\ & = & R p 320.752 .246,00 / \text { proyek }\end{array}$

